\title{
A hybrid fuzzy MCDM approach for sustainable project portfolio selection problem and an application for a construction company*
}

\author{
Gülçin Bektur \\ Dr.Öğr. Üyesi, İskenderun Teknik Üniversitesi \\ gulcin.bektur@iste.edu.tr \\ (D) 0000-0003-4313-7093
}

\section{ÖZ}

Although the construction sector is an indispensable sector in meeting human needs, it also has negative environmental and social effects. The construction industry has environmental impacts due to its significant share in consuming scarce resources and big amount of greenhouse gas emissions to the atmosphere. It is also a labor force-intensive industry. Due to the intensity of the labor force, ignoring social concerns cause a negative social image. Consequently, taking sustainability into consideration for construction projects is of great importance in terms of solutions to social and environmental problems. Due to limited resources, it is not possible to implement every project for companies. The most suitable projects are preferred among alternative projects. The problem of project portfolio selection (PPS) is an important decision problem that companies frequently encounter. Many factors should be taken into consideration for selecting projects. In many studies in the literature, the problem of PPS is addressed only by considering economic criteria. In this study, the problem of PPS is addressed with sustainability consideration. Considering sustainability, environmental and social factors have also been taken into account besides economic factors. A hybrid fuzzy multi-criteria decision-making (FMCDM) approach has been used due to uncertainties in the decision process. In the hybrid approach, the methods of Fuzzy complex proportional assessment (F-COPRAS) and Fuzzy step-wise weight assessment ratio analysis (FSWARA) are used together. An application is conducted for a construction company.

Keywords: Project Portfolio Selection Problem, Hybrid Fuzzy Multi Criteria Decision Making Method, Fuzzy SWARA, Fuzzy COPRA

JEL Codes: D81, G11, C54, C18.

\section{Sürdürülebilir proje portföy seçim problemine hibrit bulanık ÇKKV yaklaşımı ve bir inşaat firması için bir uygulama}

\begin{abstract}
öZ
İnşaat sektörü insan ihtiyaçlarının karşılanmasında vazgeçilmez bir sektör olmakla birlikte, olumsuz çevresel ve sosyal etkileri olan bir sektördür. İnşaat sektörü, kıt kaynakların tüketimindeki önemli payı ve atmosfere büyük miktarda sera gazı emisyonu nedeniyle çevresel etkilere sahiptir. Aynı zamanda işgücü yoğun bir endüstridir. İşgücünün yoğunluğundan dolayı sosyal kaygıların göz ardı edilmesi olumsuz bir sosyal imaja neden olmaktadır. Dolayısıyla inşaat projelerinde sürdürülebilirliğin dikkate alınması sosyal ve çevresel sorunların çözümü açısından büyük önem taşımaktadır. Kaynakların kısıtlı olmasından dolayı her projeyi firmaların hayata geçirmesi mümkün değildir. Alternatif projeler arasında en uygun projeler tercih edilmektedir. Proje portföy seçimi (PPS), şirketlerin sıklıkla karșılaștı̆ı önemli bir karar problemidir. Proje seçerken birçok faktör dikkate alınmalıdır. Literatürdeki birçok çalışmada PPS problemi sadece ekonomik kriterler dikkate alınarak ele alınmaktadır. Bu çalışmada, sürdürülebilirlik dikkate alınarak PPS problemi ele alınmıştır. Sürdürülebilirlik göz önünde bulundurularak ekonomik faktörlerin yanı sıra çevresel ve sosyal faktörler de dikkate alınmıștır. Karar sürecindeki belirsizlikler nedeniyle bulanık bir yaklaşım kullanılmıştır. Problemin çözümü için hibrit bulanık çok kriterli karar verme (ÇKKV) yaklaşımı kullanılmaktadır. Alternatif projelerin sürdürülebilirlik açısından değerlendirilmesinde Bulanık karmaşık orantılı değerlendirme (F-COPRAS) ve Bulanık adım adım ağırlık değerlendirme oran analizi (F-SWARA) yöntemleri birlikte kullanılmaktadır. Önerilen yöntem bir inșaat firmasında uygulanmıștır.
\end{abstract}

Anahtar Kelimeler: Proje Portföy Seçimi Problemi, Hibrit Bulanık Çok Kriterli Karar Verme Yöntemi, Bulanık SWARA, Bulanık COPRAS

JEL Kodları: D81, G11, C54, C18.

\footnotetext{
* Atıf vermek için/To cite: “Bektur, G. (2021). A hybrid fuzzy MCDM approach for sustainable project portfolio selection problem and an application for a construction company. KOCATEPEIIBFD, 23(2), 182-194. https://doi.org/10.33707/akuiibfd.911236

Sorumlu Editör/Handling Editor: Prof.Dr. Fatih Ecer

1 Sorumlu Yazar/Corresponded Author
} 


\section{Introduction}

The construction industry has a positive impact on human life quality. Most socio-economic needs can be met by the buildings and infrastructure made by the construction industry. But industry has a significant share in the consumption of scarce resources. The construction industry consumes $60 \%$ of raw material, $40 \%$ of energy and $12 \%$ of water. In addition, it causes more than $40 \%$ greenhouse gas emission (Goel et al., 2019, p. 2). In addition, the construction industry is an indispensable industry in meeting human needs. It is also the industry that provides the most employment. Because it is a labor-intensive industry, lack of employee friendly practices and ignoring social concerns cause a negative social image. Almost half of occupational accidents occur in the construction industry. Employees are exposed to a 50\% higher risk of occupational injury than in other large industries (Stanitsas et al., 2021, p. 3). Environmental and social negative impacts are very common in developing economies where sustainability is not taken into account. Governments, non-governmental organizations and civil society organizations put pressure on construction companies to considering sustainability (Goel et al., 2019, p. 2). Sustainability is achieved by taking into account triple bottom line (TBL) concerns in project management. It is aimed to reduce the environmental and social problems encountered in the management of construction projects by taking into account environmental and social factors as well as economic factors. However, despite the importance of sustainability in the construction sector, decisions are still made by considering only economic factors in many studies (Mavi \& Standing, 2018, p. 751).

Today, many organizations work in a project-oriented manner. It is not possible for organizations to realize all projects due to scarce resources. Organizations prefer the most suitable project(s) among alternative projects. In the literature, the problem of project portfolio selection (PPS) is defined as determining the most suitable project(s) among alternative projects compatible with the targets of the organizations (RezaHoseini et al., 2020, p. 3). Effective decisions on the PPS problem is very important for organizations. Because, as a result of choosing the wrong project portfolio, unnecessary usage or waste of resources of the organization may be accured or the organization may lose profit or reputation. Organizations need to evaluate alternative projects according to many different criteria in order to make a right decision on PPS problem. In the evaluation process, the usage of non-analytical methods causes not making the right decision on the PPS problem. Multi-criteria decision-making methods constitute the analytical methods used in the evaluation of alternatives according to the criteria. In the PPS problem, the decision process can be managed properly by using MCDM methods (Stanitsas et al., 2021, p. 3).

In this study, PPS problem is addressed considering sustainability. A methodology is proposed for the sustainable PPS problem. The originality of the study is F- SWARA and F- COPRAS methods are hybridized for the sustainable PPS problem for the first time. In addition, a fuzzy approach is addressed, and an application is conducted for a construction company. The aim of this study is selecting the most suitable project for the company considering sustainability. A methodology has been addressed for solving the problem. In the methodology, FMCDM methods are used together. With the integrated approach, the advantages of different methods have been utilized. The methodology can be applied by companies facing similar problems. The determined criteria can be used for other MCDM methods for the problem of PPS.

The article consists of six sections. The first section is the introduction. In the second section, literature review is given. In the third section, proposed methodology is presented. In the forth section an application is carried out for a construction company. In the fifth section sensitivity analysis and manageral implications are given. The last section is the conclusion section.

\section{Literature Review}

In the literature review studies about the problem of PPS were included. In addition, studies on F- SWARA and F- COPRAS methods are given.

Khalili- Damghani and Sadi- Nezhad, suggested a decision support system for multi- objective sustainable PPS problem (Khalili- Damghani \& Sadi- Nezhad , 2013a, p. 1045). TOPSIS and fuzzy goal programming is used for the solution of the problem. The method was applied for financial and credit institute. KhaliliDamghani and Sadi- Nezhad, used F- TOPSIS and goal programming (GP) for sustainable PPS problem. An application was presented for Iranian financial and credit institute (Khalili- Damghani \& Sadi- Nezhad, 2013b, p. 339). Sanchez, suggested a methodology for sustainable PPS problem. Decision envelopment analysis (DEA) is used for the solution of the problem (Sanchez , 2015, p. 319). Tofighian and Naderi, proposed a mathematical model and ant colony algorithm for the multi- objective project selection and 
scheduling problem (Tofighian \& Naderi, 2015, p. 30). Hosseininasab and Shetab- Boushehri, addressed the project selection and scheduling problem for road construction projects. They proposed three different mathematical model and heuristic algorithm (Hosseininasab \& Shetab- Boushehri, 2015, p. 762). Huang et al., accepted some parameters as uncertain for the project selection and scheduling problem. Heuristic algorithm was proposed to solve the problem (Huang et al., 2016, p. 1). Amirian and Sahraeian, proposed a multi-objective mathematical model and heuristic for the problem. Some parameters were considered as grey (Amirian \& Sahraeian, 2017, p. 141). Shariatmadari et al., considered the problem with resource management problem. Gravitational search algorithm was applied to address problem. The objective function was cost minimization and the problem was handled for a single objective function (Shariatmadari et al., 2017, p. 39). Kudratova et al., suggested a mathematical model for sustainable project selection and scheduling problem with reinvestment strategy. An industrial application was presented (Kudratova et al., 2018, p. 469). Kumar et al., proposed Tabu Search algorithm for the problem. Problem has single objective function. Interdependencies between projects were taken into account (Kumar et al., 2018, p. 121). Mavi and Standing, suggested a methodology for sustainable PPS problem. Fuzzy DEMATEL and ANP were used for the solution of the problem. An application was presented for the construction projects (Mavi \& Standing, 2018, p. 751). Shafahi and Haghani, assumed that some projects have phases for the project selection and scheduling problem. The objective function was maximization of the net present value. The dependency between different phases in a project was taken into account. Heuristic and mathematical models were proposed for the problem (Shafahi and Haghani., 2018, p. 47). Perez et al., considered fuzzy parameters for the problem. They took into account different relationships between projects such as synergies, incompatibilities, time order etc. An application was made for Spanish state university (Perez et al., 2018, p. 117). Habibi et al., proposed multi- objective heuristic algorithms for the problem with material ordering. An application of the method is presented for trackbed construction projects (Habibi et al., 2019, p. 690). Nemati- Lafmejani et al., proposed a heuristic algorithm for multi- mode project selection and scheduling problem. Objective functions were minimization of the total cost and makespan of the project (Nemati- Lafmejani et al., 2019, p. 105). Song et al., accepted criteria weights as uncertain for the multiobjective project selection and scheduling problem. Stochastic multi-criteria acceptability analysis method was suggested for the solution of the problem. An application was made for a hospital (Song et al., 2019, p. 793). Wu et al., used FMCDM method and zero- one programming model to sustainable renewable energy project selection and scheduling problem. A case study was carried out for a power generation enterprise (Wu et al., 2019, p. 69). Sarnataro et al., proposed a multi- objective optimization model for the problem. The application was made for urban planning projects (Sarnataro et al., 2020, p.1). Miralinaghi et al., examined the problem of urban road project selection problem. The problem was formulated as a bi- level programming (Miralinaghi et al., 2020, p. 580).

Some problems that the F-SWARA method has been successfully implemented are evaluating solutions to supply chain management problems (Agarwal et al., 2020, p. 1), designing a sustainable airport (Kaya \& Erginel 2020), selection of third-party reverse logictics provider (Zarbakhshnia et al., 2018, p. 307), evaluation of construction equipment (Ghorabaee et al., 2018, p. 32) and assessing the key challenges of digital health interventions (Mardani et al., 2020, p. 1).

COPRAS has been successfully applied in solving different problems such as ranking of renewable energy sources (Alkan \& Albayrak, 2020, p. 712), selection of strategy for wind farms (Dhiman et al., 2020, p. 1), roll-up site selection (Schitea et al., 2019,p. 8585), healthcare evaluations (Mishra et al., 2020, p. 1).

\section{The Proposed Methodology}

F-SWARA and F-COPRAS methods are used in the evaluation of alternative projects according to sustainability. Fuzzy logic was taken into account due to the uncertainty in the evaluation process. The criteria and sub-criteria are weighted using F-SWARA method. The F-COPRAS method is used to evaluate the alternatives according to the criteria. The use of fuzzy logic is more recommended than deterministic models due to the uncertainty of the decision maker is taken into account. The criterion weights obtained from the F- SWARA method are taken into account for the application of F- COPRAS. Today, many multicriteria decision-making methods are available in the literature. Choosing the right methods significantly affects the success in the decision process. F- SWARA and F- COPRAS methods are suitable for hybrid usage and were chosen among other methods considering the advantages of the methods. In SWARA, the number of comparisons is less than other MCDM methods such as AHP. There is no need to check the consistency of judgements. COPRAS is suitable to use in a fuzzy approach. It takes into account the ratios of the best and 
worst solution simultaneously, and the rank of the alternatives can be obtained in less time. The representation of the approach is given in Graph 1.

Graph 1: Hybrid Usage of F- SWARA and F- COPRAS

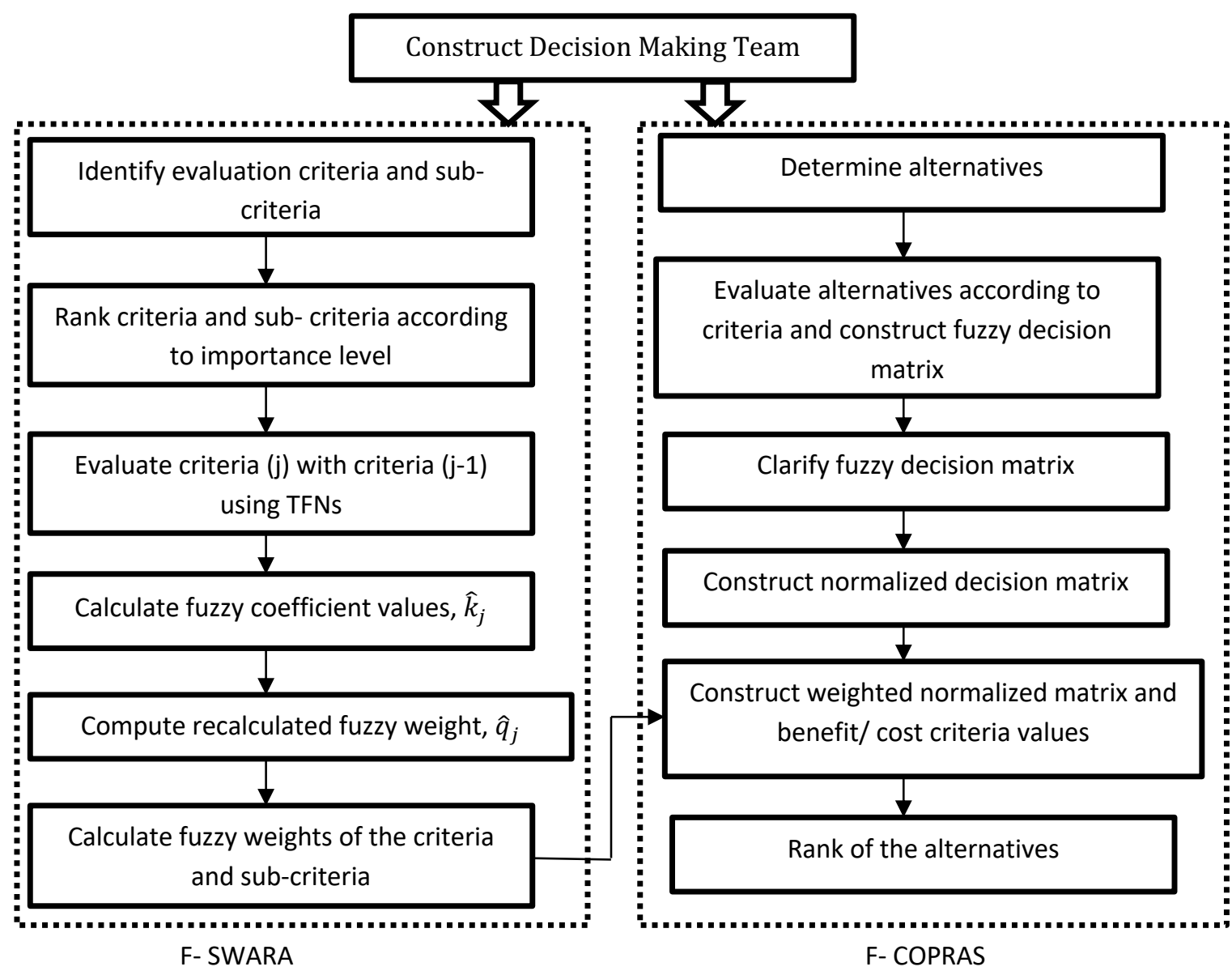

Definition: In fuzzy set theory, conversion scales are used to transform linguistic variables into fuzzy numbers. Fuzzy numbers and linguistic expressions are given in Table 1 (Zadeh, 1965, p. 338).

Table 1: Triangular fuzzy numbers and linguistic variables

\begin{tabular}{lr}
\hline Linguistic variable & TFN \\
\hline Extremely unimportant & $(0 ; 0 ; 0,1)$ \\
Not very important & $(0 ; 0,1 ; 0,3)$ \\
Not important & $(0,1 ; 0,3 ; 0,5)$ \\
Fair & $(0,3 ; 0,5 ; 0,7)$ \\
Important & $(0,5 ; 0,7 ; 0,9)$ \\
Very important & $(0,7 ; 0,9 ; 1)$ \\
Extremely important & $(0,9 ; 1 ; 1)$ \\
\hline
\end{tabular}

\section{III.I. Fuzzy SWARA}

The SWARA method was proposed by (Kersuliene et al., 2010, p. 243). It is a successful multi- criteria decision making (MCDM) method especially used for weighting evaluation criteria. Due to imprecise and vague information, SWARA can be organized with a fuzzy approach. Steps of the F- SWARA is given below (Kaya \& Erginel, 2020, p. 2): 
Step 1: By considering decision making (DM) team, criteria and sub-criteria are sorted from the most important to the least important. The first criterion is the most important, while the last criterion is the least important.

Step 2: Starting with the 2nd place criterion, the comparison of the criteria $\mathrm{j}$ with the previous criteria (j1 ) is made by taking into account Table 1 . This value is expressed as $\hat{S}_{j}$.

Step 3: Calculate the fuzzy coefficient, $\hat{k}_{j}$ using Equation 1.

$\hat{k}_{j}= \begin{cases}1 ; & j=1 \\ \hat{S}_{j}+1 ; & j>1\end{cases}$

Step 4: Compute $\hat{q}_{j}$ values for each criterion using Equation 2.

$\hat{q}_{j}= \begin{cases}1 ; & j=1 \\ \frac{\hat{q}_{j}-1}{\hat{k}_{j}} ; & j>1\end{cases}$

Step 5: Calculate fuzzy weight $\left(\widehat{w}_{j}\right)$ of the each criterion using Equation 3.

$\widehat{w}_{j}=\frac{\hat{q}_{j}}{\sum_{k=1}^{n} \hat{q}_{k}}$

Step 6: Defuzzification of the $\widehat{w}_{j}$ using Equation 4.

$w_{j}=\frac{1}{3}\left(\widehat{w}_{j \alpha}+\widehat{w}_{j \beta}+\widehat{w}_{j \gamma}\right)$

\section{III.II. Fuzzy COPRAS}

COPRAS, is one of the MCDM method proposed by (Zavadskas et al., 1994, p. 131). COPRAS method is used in the evaluation of alternatives in an efficient way (Alkan \& Bayrak, 2020, p. 712). Fuzzy COPRAS (FCOPRAS) method has been proposed to remove uncertainty in the decision process.

In the COPRAS method, criterion weights are taken into account. In the scope of the study, criterion weights were determined by the F-SWARA method. Steps of the F- COPRAS (Schitea et al., 2019, p. 8585):

Step 1: Construction of fuzzy decision matrix

With number of $\mathrm{m}$ alternatives and number of $\mathrm{n}$ criteria, $\tilde{x}_{i j}$ denotes fuzzy performance value obtained from the evaluation of alternative i according to the criteria $\mathrm{j}$. The triangular fuzzy number $\tilde{x}_{i j}$ consists of the parameters $\tilde{x}_{i j}=\left(x_{i j}^{l}, x_{i j}^{m}, x_{i j}^{u}\right)$ and given in the Table 2 (Zadeh, 1965, p. 338). $\tilde{X}$ decision matrix consisting of fuzzy performance values of $\tilde{x}_{i j}$.

Table 2: Triangular fuzzy numbers and linguistic variables

\begin{tabular}{lr}
\hline Linguistic variables & TFN \\
\hline Very poor & $(0,0,1)$ \\
Poor & $(0,1,3)$ \\
Little poor & $(1,3,5)$ \\
Fair & $(3,5,7)$ \\
Little good & $(5,7,9)$ \\
Good & $(7,9,10)$ \\
Very good & $(9,10,10)$ \\
\hline
\end{tabular}

$\tilde{X}=\left[\tilde{x}_{i j}\right]_{m * n}=\left[\begin{array}{cccc}\tilde{x}_{11} & \tilde{x}_{12} & \cdots & \tilde{x}_{1 n} \\ \tilde{x}_{21} & \tilde{x}_{22} & \cdots & \tilde{x}_{2 n} \\ \vdots & \vdots & \ddots & \vdots \\ \tilde{x}_{m 1} & \tilde{x}_{m 2} & \cdots & \tilde{x}_{m n}\end{array}\right] \quad \forall i, j$ 
In case of for more than one decision maker, parameters belonging to group performance value are given Equations (5-7).

$x_{i j}^{l}=\min _{k}\left\{x_{i j k}^{l}\right\}$

$x_{i j}^{m}=\frac{1}{K} \sum_{k=1}^{K} x_{i j k}^{m}$

$x_{i j}^{u}=\max _{k}\left\{x_{i j k}^{u}\right\}$

Step 2: Construction of decision matrix

The fuzzy numbers that make up the decision matrix are converted into crisp numbers and the decision matrix is formed with exact values. Best Nonfuzzy Performance (BNP) was used to transform fuzzy numbers (see Equation 8).

$x_{i j}=\frac{\left[\left(x_{i j}^{u}-x_{i j}^{l}\right)+\left(x_{i j}^{m}-x_{i j}^{l}\right)\right]}{3}+x_{i j}^{l}$

Step 3: Construction of normalized decision matrix

Normalized decision matrix is constructed with the Equation 9.

$\bar{x}_{i j}=\frac{x_{i j}}{\sum_{i=1}^{m} x_{i j}}$

Step 4: Construction of weighted normalized decision matrix by the Equation 10.

$\hat{x}_{i j}=\bar{x}_{i j} w_{j}$

Step 5: Calculation of total weighted normalized values based on benefit and cost measures by Equations 11 and 12.

$S_{+i}=\sum_{j=1}^{k} \hat{x}_{+i j} \quad \forall i$

$S_{-i}=\sum_{j=k+1}^{n} \hat{x}_{-i j} \quad \forall i$

$\hat{x}_{+i j}$ and $\hat{x}_{-i j}$ denote weighted normalized performance values with benefit and cost criteria, respectively.

Step 6: Calculation of relative importance values by the Equations 13 and 14.

$Q_{i}=S_{+i}+\frac{S_{-\min } \sum_{i=1}^{m} S_{-i}}{S_{-i} \sum_{i=1}^{m}\left(\frac{S_{-\min }}{S_{-i}}\right)} \quad \forall i$

$S_{-\min }=\min _{i}\left\{S_{-i}\right\}$

Step 7: Calculation of performance index values by the Equation 15.

$P_{i}=\left[\frac{Q_{i}}{Q_{\max }}\right] \times 100 \forall i$

Step 8: Evaluation of alternatives according to $P_{i}$ values.

An alternative preference order is obtained by ordering the obtained $P_{i}$ values in descending order.

\section{An Application in a Construction Company}

The methodology has been applied in a project-oriented company that has been operating for the construction industry for nearly 25 years. Company's head office is in Ankara. The company does not only provide service in Ankara. It takes on projects from different cities and countries. The company has the aim of being a company that respects people and nature. Therefore, sustainability is an important criterion for the company. 
The company also attaches importance to sustainability as a new strategy while evaluating projects. Thus, the application was not only carried out to demonstrate the effectiveness of the methodology, but it was also aimed to make a decision in accordance with the new strategy of the company. It is aimed to solve the PPS problem of it. Each step of the methodology has been implemented in this section.

\section{IV.I. Determination of the Criteria}

First of all, a decision making (DM) team is formed to determine evaluation criteria and evaluate the alternatives. DM team consists of 2 project managers, 2 academicians and 1 project employee. The criteria and sub-criteria determined by considering the literature and DM team opinions and given below. Accordingly, there are 3 main criteria as economic, environmental and social criteria. Criteria and subcriteria are given below.

\section{Environmental criteria (C1)}

Usage of the environmentally friendly products (C11) refers to products are designed with the concern of reducing environmental impact throughout their life cycle by extracting and acquiring of raw materials. High usage of environmentally friendly products is preferred.

Green transportation (C12) refers to considering environmental issues in transportation such as clean fuel, etc. The greener transportation during a project, the better the score of the project.

Waste management refers to (C13) decrease the amount of resources consumed, confirm that resources that are taken from nature are reused as many times as possible and that the amount of waste is kept to a minimum.

\section{Economic criteria (C2)}

Coordination of project implementation by organizational strategy (C21) refers to the compatibility of the project with the areas that the company serves and contributing to the organization's goals.

Possibility of success (C22) refers to the satisfaction of the expectation of the client and the company by the completion of the project. The aim is to choose projects that will provide customer satisfaction as much as possible. In addition, projects that will have a positive impact on the company's reputation are preferred.

Internal return rate $(\mathrm{C} 23)$ refers to the profitability of potential investments. The internal return rate is desired to be higher by the companies.

Social criteria (C3)

Employee satisfaction (C31) refers to long- term and short term benefits of employee, such as creating a work environment where employees have decision- making power and creating a business environment where they can develop themselves professionally in different fields.

The positive social impact of project implementation (C32) refers to the social contributions of project outputs within the company and in society. The high positive social impact of projects is one of the reasons for preference.

Employee health and safety (C33) refers to the working conditions of the employees throughout the project in terms of safety and health. Projects in which all kinds of safety of employees are ensured during the project are preferred.

\section{IV.II. Determination of Criterion Weights Using F- SWARA}

F- SWARA is used for determination of the criteria weights.

Step 1. Sort criteria and sub-criteria according to importance level

Criteria and sub- criteria are sorted in a descending order by taking into account DM team opinions.

Step 2. Comparison of the criteria $j$ with the previous criteria (j-1) 
The criteria are compared with each other, taking into account Table 1. Comparison results are denoted as $\widehat{\mathrm{S}}_{\mathrm{j}}$ and given in Table 3 .

Step 3: Calculate the fuzzy coefficient $\left(\hat{k}_{j}\right)$ values using Equation 3. $\hat{k}_{j}$ values are calculated and given in Table 3.

Step 4: Calculate $\hat{q}_{j}$ values using Equation 4. $\hat{q}_{j}$ values are calculated and given in Table 3.

Step 5: Calculate fuzzy weight $\left(\widehat{w}_{j}\right)$ using Equation 5. $\widehat{w}_{j}$ values are calculated and given in Table 3.

Step 6: Defuzzification of the $\widehat{w}_{j}$ values using Equation 6. $w_{\mathrm{j}}$ values are given in Table 3.

Alternatives are compared considering the $\widehat{w}_{j}$ values using F- COPRAS.

Table 3. Calculations of F- SWARA

\begin{tabular}{llllll}
\hline $\begin{array}{l}\text { Sub- } \\
\text { Criteria }\end{array}$ & $\hat{\mathrm{S}}_{\mathrm{j}}$ & $\hat{\mathrm{k}}_{\mathrm{j}}$ & $\hat{\mathrm{q}}_{\mathrm{j}}$ & $\widehat{\mathrm{w}}_{\mathrm{j}}$ & $\mathrm{w}_{\mathrm{j}}$ \\
\hline C13 & & $(1 ; 1 ; 1)$ & $(1 ; 1 ; 1)$ & $(0.189 ; 0.278 ; 0.364)$ & 0.277 \\
C11 & $(0.1 ; 0.3 ; 0.5)$ & $(1.1 ; 1.3 ; 1.5)$ & $(0.666 ; 0.769 ; 0.909)$ & $(0.172 ; 0.214 ; 0.242)$ & 0.209 \\
C12 & $(0.3 ; 0.5 ; 0.7)$ & $(1.3 ; 1.5 ; 1.7)$ & $(0.392 ; 0.512 ; 0.699)$ & $(0.132 ; 0.142 ; 0.143)$ & 0.139 \\
C22 & $(0.3 ; 0.5 ; 0.7)$ & $(1.3 ; 1.5 ; 1.7)$ & $(0.230 ; 0.341 ; 0.537)$ & $(0.084 ; 0.095 ; 0.102)$ & 0.093 \\
C23 & $(0 ; 0.1 ; 0.3)$ & $(1 ; 1.1 ; 1.3)$ & $(0.177 ; 0.310 ; 0.537)$ & $(0.064 ; 0.086 ; 0.102)$ & 0.084 \\
C21 & $(0.1 ; 0.3 ; 0.5)$ & $(1.1 ; 1.3 ; 1.5)$ & $(0.118 ; 0.239 ; 0.489)$ & $(0.043 ; 0.066 ; 0.092)$ & 0.067 \\
C33 & $(0.3 ; 0.5 ; 0.7)$ & $(1.3 ; 1.5 ; 1.7)$ & $(0.069 ; 0.159 ; 0.376)$ & $(0.025 ; 0.044 ; 0.071)$ & 0.047 \\
C32 & $(0 ; 0.1 ; 0.3)$ & $(1 ; 1.1 ; 1.3)$ & $(0.053 ; 0.144 ; 0.376)$ & $(0.019 ; 0.040 ; 0.071)$ & 0.043 \\
C31 & $(0.1 ; 0.3 ; 0.5)$ & $(1.1 ; 1.3 ; 1.5)$ & $(0.035 ; 0.111 ; 0.341)$ & $(0.013 ; 0.031 ; 0.064)$ & 0.036 \\
\hline
\end{tabular}

The higher criterion weight indicate that the criterion is important. The criteria are ranked according to importance in Table 3.Considering Table 3, it is seen that the most important criteria are those related to environmental. The most important criterion is C13 criterion and its weight is 0,277. According to importance, environmental criteria are followed by economic and social criteria.

\section{IV.III. Evaluation of Alternatives Using F- COPRAS}

Step 1: Construction of fuzzy decision matrix

The evaluation of alternatives according to the criteria was made in accordance with Table 2 by DM team. The obtained results are converted into a single value by considering Equation 5, 6 and 7. The obtained fuzzy decision matrix is given in Table 4.

Table 4: Fuzzy decision matrix

\begin{tabular}{|c|c|c|c|c|c|c|c|c|c|c|c|c|c|c|c|c|c|c|c|c|c|c|c|c|c|c|c|}
\hline \multirow{3}{*}{$\begin{array}{c}\text { Alt. } \\
1\end{array}$} & \multicolumn{27}{|c|}{ Criteria } \\
\hline & \multicolumn{4}{|c|}{ C11 } & \multicolumn{3}{|c|}{ C12 } & \multicolumn{3}{|c|}{ C13 } & \multicolumn{2}{|c|}{$\mathrm{C} 21$} & \multicolumn{3}{|c|}{$\mathrm{C} 22$} & \multicolumn{3}{|c|}{$\mathrm{C} 23$} & \multicolumn{3}{|c|}{ C31 } & \multicolumn{3}{|c|}{ C32 } & \multicolumn{3}{|c|}{ C33 } \\
\hline & 1 & 3 & 5 & 0 & 3 & 5 & 0 & 4 & 9 & 0 & 3 & 7 & 0 & 3 & 5 & 0 & 3 & 7 & 0 & 4 & 9 & 0 & 3 & 7 & 0 & 3 & 9 \\
\hline 2 & 0 & 2 & 7 & 0 & 3 & 10 & 0 & 1 & 5 & 0 & 3 & 10 & 0 & 5 & 10 & 0 & 5 & 10 & 0 & 5 & 10 & 0 & 4 & 10 & 0 & 5 & 10 \\
\hline 3 & 0 & 2 & 5 & 0 & 1 & 3 & 0 & 1 & 3 & 0 & 2 & 7 & 0 & 3 & 7 & 0 & 3 & 7 & 0 & 3 & 9 & 0 & 3 & 10 & 0 & 2 & 9 \\
\hline 4 & 0 & 6 & 10 & 3 & 8 & 10 & 0 & 6 & 10 & 0 & 5 & 10 & 5 & 9 & 10 & 0 & 7 & 10 & 3 & 8 & 10 & 0 & 5 & 10 & 5 & 8 & 10 \\
\hline 5 & 0 & 3 & 7 & 0 & 2 & 9 & 0 & 2 & 7 & 0 & 3 & 9 & 0 & 2 & 5 & 0 & 1 & 5 & 0 & 1 & 3 & 0 & 2 & 5 & 0 & 2 & 5 \\
\hline 6 & 7 & 9 & 10 & 5 & 7 & 9 & 5 & 8 & 10 & 3 & 7 & 10 & 5 & 7 & 10 & 5 & 8 & 10 & 5 & 8 & 10 & 1 & 7 & 10 & 5 & 8 & 10 \\
\hline 7 & 1 & 5 & 10 & 1 & 5 & 9 & 3 & 7 & 10 & 3 & 7 & 10 & 1 & 5 & 10 & 3 & 5 & 9 & 0 & 5 & 10 & 1 & 6 & 10 & 0 & 6 & 10 \\
\hline
\end{tabular}


Step 2: Construction of decision matrix

The fuzzy numbers are converted to crisp numbers using Equation 10 and the decision matrix is given in Table 5 .

Table 5: Decision Matrix

\begin{tabular}{cccccccccc}
\hline & C11 & C12 & C13 & C21 & C22 & C23 & C31 & C32 & C33 \\
\hline 1 & 3 & 2.534 & 4.4 & 3.33 & 2.53 & 3.47 & 4.4 & 3.2 & 4 \\
2 & 2.934 & 4.2 & 2.13 & 4.2 & 5 & 4.87 & 5.13 & 4.73 & 5.13 \\
3 & 2.267 & 1.334 & 1.33 & 3.07 & 3.2 & 3.33 & 4.13 & 4.2 & 3.73 \\
4 & 5.267 & 6.934 & 5.4 & 5.13 & 7.87 & 5.67 & 6.93 & 5 & 7.73 \\
5 & 3.334 & 3.734 & 3.07 & 3.87 & 2.27 & 2.13 & 1.33 & 2.4 & 2.27 \\
6 & 8.667 & 7 & 7.6 & 6.8 & 7.47 & 7.73 & 7.6 & 6 & 7.73 \\
7 & 5.467 & 5 & 6.67 & 6.53 & 5.33 & 5.8 & 5 & 5.6 & 5.4 \\
\hline
\end{tabular}

Steps 3 and 4: Construction of normalized decision matrix and weighted normalized decision matrix

Decision matrix is normalized using Equation 9. Weighted normalized decision matrix is constructed using Equation 10 and given in Table 6.

Table 6: Weighted normalized decision matrix

\begin{tabular}{cccccccccc}
\hline & C11 & C12 & C13 & C21 & C22 & C23 & C31 & C32 & C33 \\
\hline 1 & 0.021 & 0.012 & 0.04 & 0.008 & 0.008 & 0.01 & 0.006 & 0.005 & 0.007 \\
2 & 0.01 & 0.01 & 0.01 & 0.005 & 0.008 & 0.007 & 0.003 & 0.004 & 0.004 \\
3 & 0.016 & 0.006 & 0.012 & 0.007 & 0.01 & 0.009 & 0.005 & 0.006 & 0.006 \\
4 & 0.018 & 0.016 & 0.025 & 0.006 & 0.012 & 0.008 & 0.005 & 0.004 & 0.006 \\
5 & 0.022 & 0.016 & 0.027 & 0.008 & 0.007 & 0.006 & 0.002 & 0.004 & 0.004 \\
6 & 0.037 & 0.02 & 0.043 & 0.01 & 0.014 & 0.014 & 0.006 & 0.006 & 0.008 \\
7 & 0.025 & 0.016 & 0.041 & 0.01 & 0.011 & 0.011 & 0.004 & 0.006 & 0.006 \\
\hline
\end{tabular}

Step 5,: Calculation of $S_{+i}$ and $S_{-i}$ using Equations 11 and 12. Due to all criteria are benefit type criteria, $S_{-i}$ values are equal to zero.

Step 6: $Q_{i}$ values are calculated using Equation 13. Due to all $S_{-i}$ values are equal to zero, $Q_{i}$ values are equal to $S_{+i}$ values and given in Table 7 .

Step 7: $P_{i}$ values are calculated by Equation 15. And given in Table 7.

Table 7: Relative importance and index values

\begin{tabular}{lcc}
\hline Alternatives & $Q_{i}$ & $P_{i}$ \\
\hline 1 & 0.111 & 0.729 \\
2 & 0.057 & 0.374 \\
3 & 0.074 & 0.484 \\
4 & 0.097 & 0.636 \\
5 & 0.091 & 0.598 \\
6 & 0.153 & 1 \\
7 & 0.125 & 0.822 \\
\hline
\end{tabular}

$P_{i}$ shows the sustainability score of each alternative. According to Table 7, Project 6 is the most suitable project for the company. The rank of the projects is Project 6, Project 7. Project 1, Project 4, Project 5, Project 3, Project 2. 


\section{Sensitivity Analysis}

Sensitivity analysis was conducted to examine the effect of the different criterion weights on the rank of the alternatives. For this purpose, different criterion weights were determined for 10 different scenarios. The current situation and each scenario are denoted by CS and Sci $(i=1, \ldots, 10)$, respectively. Criteria weights for each scenario are given in Table 8. All scenarios were evaluated with the F-COPRAS method. The obtained index values for each scenario are given in Graph 2 and Table 9.

Table 8: Weights of the criteria for each scenario

\begin{tabular}{llllllllll}
\hline Scenario & C11 & C12 & C13 & C21 & C22 & C23 & C31 & C32 & C33 \\
\hline CS & 0.209 & 0.139 & 0.277 & 0.067 & 0.093 & 0.084 & 0.036 & 0.043 & 0.047 \\
1 & 0.111 & 0.111 & 0.111 & 0.111 & 0.111 & 0.111 & 0.111 & 0.111 & 0.111 \\
2 & 0.18 & 0.11 & 0.25 & 0.07 & 0.12 & 0.09 & 0.05 & 0.06 & 0.07 \\
3 & 0.17 & 0.11 & 0.23 & 0.08 & 0.11 & 0.11 & 0.06 & 0.06 & 0.07 \\
4 & 0.15 & 0.12 & 0.2 & 0.1 & 0.1 & 0.12 & 0.07 & 0.06 & 0.08 \\
5 & 0.067 & 0.093 & 0.084 & 0.036 & 0.043 & 0.047 & 0.209 & 0.139 & 0.277 \\
6 & 0.036 & 0.043 & 0.047 & 0.209 & 0.139 & 0.277 & 0.067 & 0.093 & 0.084 \\
7 & 0.036 & 0.043 & 0.047 & 0.067 & 0.093 & 0.084 & 0.209 & 0.139 & 0.277 \\
8 & 0.209 & 0.139 & 0.277 & 0.036 & 0.043 & 0.047 & 0.067 & 0.093 & 0.084 \\
9 & 0.277 & 0.139 & 0.209 & 0.043 & 0.036 & 0.047 & 0.084 & 0.067 & 0.093 \\
10 & 0.043 & 0.036 & 0.047 & 0.093 & 0.067 & 0.084 & 0.277 & 0.209 & 0.139 \\
\hline
\end{tabular}

Table 9: Index values of the alternatives for each scenario

\begin{tabular}{llllllllllll}
\hline Alternatives & CS & Sc1 & Sc2 & Sc3 & Sc4 & Sc5 & Sc6 & Sc7 & Sc8 & Sc9 & Sc10 \\
\hline 1 & 0.729 & 0.766 & 0.748 & 0.751 & 0.755 & 0.833 & 0.756 & 0.831 & 0.765 & 0.745 & 0.842 \\
2 & 0.374 & 0.466 & 0.405 & 0.412 & 0.424 & 0.484 & 0.501 & 0.505 & 0.390 & 0.387 & 0.511 \\
3 & 0.484 & 0.625 & 0.526 & 0.537 & 0.553 & 0.690 & 0.677 & 0.731 & 0.508 & 0.514 & 0.752 \\
4 & 0.636 & 0.679 & 0.646 & 0.647 & 0.653 & 0.719 & 0.664 & 0.726 & 0.638 & 0.632 & 0.717 \\
5 & 0.598 & 0.576 & 0.593 & 0.589 & 0.589 & 0.533 & 0.562 & 0.517 & 0.603 & 0.595 & 0.522 \\
6 & 1 & 1 & 1 & 1 & 1 & 1 & 1 & 1 & 1 & 1 & 1 \\
7 & 0.822 & 0.817 & 0.822 & 0.821 & 0.821 & 0.789 & 0.838 & 0.792 & 0.820 & 0.794 & 0.807 \\
\hline
\end{tabular}

Table 10: Rank of the alternatives for each scenario

\begin{tabular}{|c|c|}
\hline Scenario & Rank of the alternatives \\
\hline $\mathrm{CS}$ & $6,7,1,4,5,3,2$ \\
\hline 1 & $6,7,1,4,3,5,2$ \\
\hline 2 & $6,7,1,4,5,3,2$ \\
\hline 3 & $6,7,1,4,3,5,2$ \\
\hline 4 & $6,7,1,4,5,3,2$ \\
\hline 5 & $6,1,7,4,3,5,2$ \\
\hline 6 & $6,7,1,3,4,5,2$ \\
\hline 7 & $6,1,7,3,4,5,2$ \\
\hline 8 & $6,7,1,4,5,3,2$ \\
\hline 9 & $6,7,1,4,5,3,2$ \\
\hline 10 & $6,1,7,3,4,5,2$ \\
\hline
\end{tabular}

According to Pi values, rank of the alternatives are given in Table 10. The most suitable project in each scenario is Project 6 . There have been minor changes on the performance index values according to the scenarios. Considering the sensitivity analysis, the company should choose the 6th project among alternative projects. Except for number of 3 scenarios, the 7th project can also be evaluated in the second sequence. 
Graph 2: Index values of the alternatives for each scenario

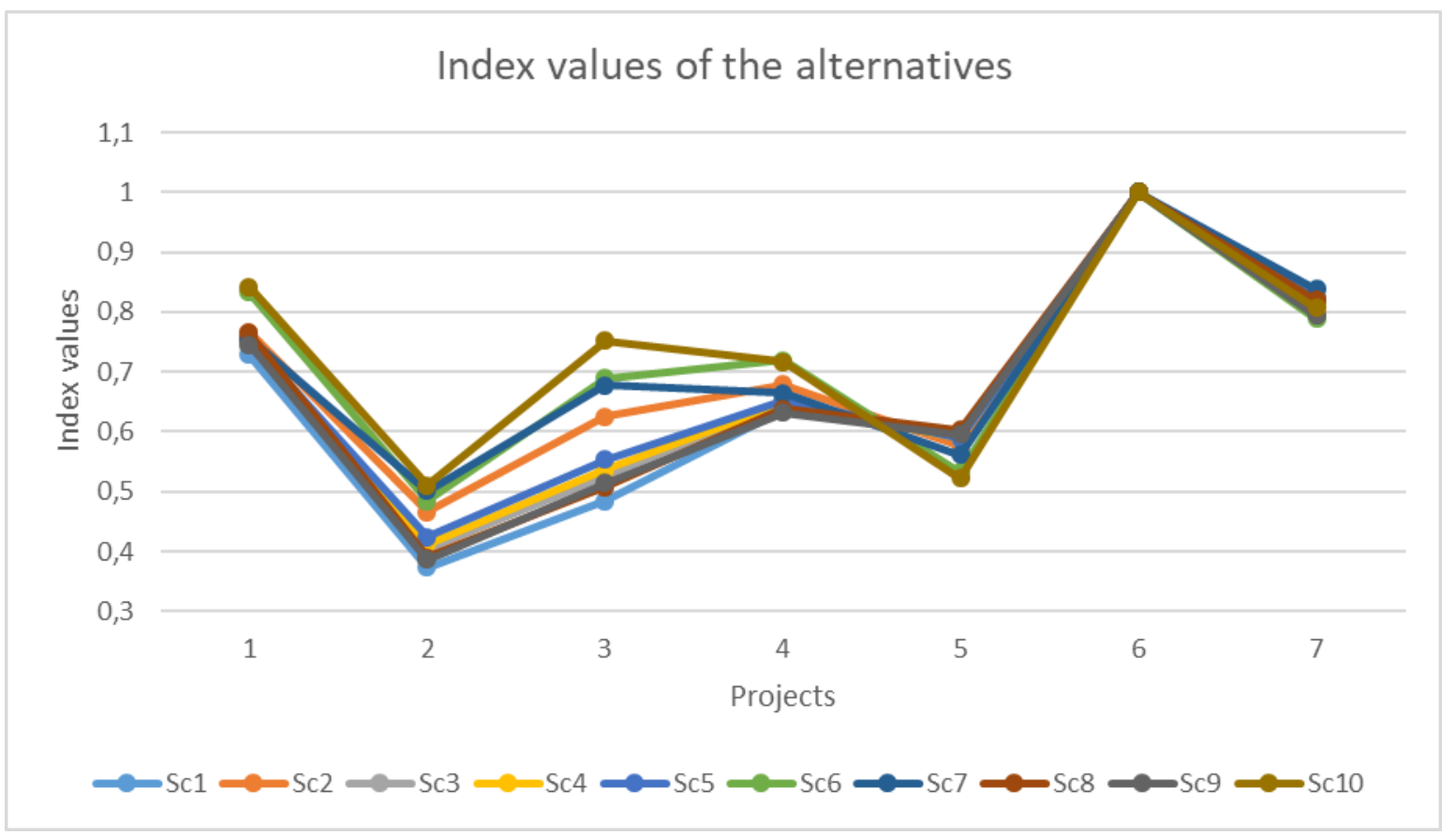

\section{Conclusions}

Although the construction sector is an indispensable sector in meeting human needs, it has negative effects on the environment. In addition, due it is a labor-intensive sector, employees' social rights cannot be ignored. In this study, the PPS problem has been handled by considering sustainability. By considering sustainability, environmental and social factors are also taken into account as well as economic factors. Organizations consider many factors when choosing their project portfolio. Different criteria are taken into account in the selection of projects among different alternative projects. For this reason, the PPS problem can be solved by using multi-criteria decision making methods. A fuzzy approach was taken into account due to the uncertainties in the decision process. Different multi-criteria decision making methods can be used as a hybrid in order to take advantage of different methods. In this study, the PPS problem has been solved by using fuzzy hybrid multi-criteria decision making methods. F-SWARA and F-COPRAS methods are used together to solve the problem. An application has been made for a construction company. As a result, the rank of alternative projects is presented to the decision maker. Resource management of the organization is not taken into account in the proposed methodology. Considering the resources of the organization, the optimal solution of the project portfolio selection problem can be found by mathematical modeling. Within the scope of the study, the problem of project portfolio selection was handled alone. A solution can be obtained by considering the project portfolio selection and project scheduling problem in an integrated manner. The proposed methodology can also be applied by other companies facing the PPS problem. In future studies, also the methodology can be applied for different sectors.

Statement of Contribution of Researchers: The author declared that the entire article is prepared by on their own.

Statement of Support and Acknowledgment: The author declared that the study is not received support from any person or institution.

Conflict Statement: The author declares that there is no conflict of interest for themselves and third parties.

Statement of Ethics Committee Report Requirement: The author states that there is no need for an ethics committee report in the article. 


\section{References}

Agarwal, S., Kant, R., \& Shankar, R. (2020). Evaluating solutions to overcome humanitarian supply chain management barriers: A hybrid fuzzy SWARA- fuzzy WASPAS approach. International Journal of Disaster Risk Reduction, 51, 101838.

Alkan, Ö., \& Albayrak, Ö.K. (2020). Ranking of renewable energy sources for regions in Turkey by fuzzy entropy based fuzzy COPRAS and fuzzy MULTIMOORA. Renewable Energy, 162, 712- 726.

Amirian, H., \& Sahraeian, R. (2017). Solving a grey project selection scheduling using a simulated shuffled frog leaping algorithm. Computers and Industrial Engieering, 107, 141- 149.

Dhiman, H.S., \& Deb, D. (2020). Fuzzy TOPSIS and fuzzy COPRAS based multi- criteria decision making for hybrid wind farms. Energy, 202, 117755.

Ghorabaee, M.K., Amiri, M., Zavadskas, E.K., \&Antucheviciene, J. (2018). A new hybrid fuzzy MCDM approach for evaluation of construction equipment with sustainability considerations. Archives of Civil and Mechanical Engineering, 18 (1), 32- 49.

Goel, A., Ganesh, L. S., \& Kaur, A. (2019). Sustainability integration in the management of construction projects: A morphological analysis of over two decades' research literature. Journal of Cleaner Production, 236, 117676.

Habibi, F., Barzinpour, F., \& Sadjadi, S. J. (2019). A mathematical model for project scheduling and material ordering problem with sustainability considerations: A case study in Iran. Computers and Industrial Engineering, 128, 690- 710.

Hosseininasab, S., \& Shetab- Boushehri, S. (2015). Integration of selecting and scheduling urban road construction projects as a time- dependent discrete network design problem. European Journal of Operational Research, 246, 762- 771.

Huang, X., Zhao, T., \& Kudratova, S. (2016). Uncertain mean- variance and mean- semivariance models for optimal project selection and scheduling. Knowledge- Based Systems, 93, 1- 11.

Kaya, S.K., \& Erginel, N. (2020). Futuristic airport: A sustainable airport design by integrating hesitant fuzzy SWARA and hesitant fuzzy sustainable quality function deployment. Journal of Cleaner Production, $275,123880$.

Kersuliene, V., Zavadskas, E.K., \& Turskis, Z. (2010). Selection of rational dispute resolution method by applying new stepwise weight assessment ratio anaysis (SWARA). Journal of Business Economics and Management, 11 (2), 243- 258.

Khalili- Damghani, K., \& Sadi- Nezhad, S. (2013). A decision support system for fuzzy multi -objective multi -period sustainable project selection. Computers and Industrial Engineering, 64, 1045- 1060.

Khalili- Damghani, K., \& Sadi- Nezhad, S. (2013). A hybrid fuzzy multiple criteria group decision making approach for sustainable project selection. Applied Soft Computing, 13, 339- 352.

Kudratova, S., Huang, X., \& Zhou, X. (2018). Sustainable project selection: optimal project selection considering sustainability under reinvestment strategy. Journal of Cleaner Production, 203, 469481.

Kumar, M., Mittal, M.L., Soni, G., \&Joshi, D. (2018). A hybrid TLBO- TS algorithm for integrated selection and scheduling of projects. Computers and Industrial Engineering, 119, 121- 130.

Mardani, A., Saraji, M.K., Mishra, A.R., \& Rani, P. (2020). A novel extended approach under hesitent fuzzy sets to design a framework for assessing the key challenges of digital health interventions adoption during the COVID- 19 outbreak. Applied Soft Computing, 96, 106613.

Mavi, R. K., \& Standing, C. (2018). Critical success factors of sustainable project management in construction: A fuzzy DEMATEL- ANP approach. Journal of Cleaner Production, 194, 751- 765.

Miralinaghi, M., Seilabi, S., Chen, S., Hsu, Y., \& Labi, S. (2020). Optimizing the selection and scheduling of multi- class projects using a Stackelberg framework. European Journal of Operational Research, 286, 508- 522.

Mishra, A.R., Rani, P., Mardani, A., Pardasani, K.R., Govindan, K., \& Alrasheedi, M. (2020). Healthcare evaluation in hazardous waste recycling using novel interval- valued intuitionistic fuzzy

Bektur, A hybrid fuzzy MCDM approach for sustainable project portfolio selection problem and an application for a construction company 
information based ob complex proportional assessment method. Computers and Industrial Engineering, 139, 106140.

Nemati- Lafmejani, R., Davari- Ardakani, H., \& Najafzad, H. (2019). Multi- mode resource constrained project scheduling and contractor selection: Mathematical formulation and metaheuristic algorithms. Applied Soft Computing Journal, 81, 105533.

Perez, F., Gomez, T., Caballero, R., \& Liern, V. (2018). Project portfolio selection and planning with fuzzy constraints. Technological Forecasting and Social Change, 131, 117- 129.

RezaHoseini, A., Ghannadpour, S. F., \& Hemmati, M. (2020). A comprehensive mathematical model for resource- constrained multi- objective Project portfolio selection and scheduling considering sustainability and projects splitting. Journal of Cleaner Production, 269, 122073.

Sanchez, M. A. (2015). Integrating sustainability issues into project management. Journal of Cleaner Production, 96, 319- 330.

Sarnataro, M., Barbati, M., \& Greco, S. (2020). A portfolio approach for the selection and the timing of urban planning projects. Socio- Economic Planning Sciences, (In press)

Schitea, D., Deveci, M., Iordache, M., Bilgili, K., Akyurt, I.Z., \& Iordache, I. (2019). Hydrogen mobility roll- up site selection using untuitionistic fuzzy sets based WASPAS, COPRAS and EDAS. International Journal of Hydrogen Energy, 44 (16), 8585- 8600.

Shafahi, A., \& Haghani, A. (2018). Project selection and scheduling for phase- able projects with interdependencies among phases. Automation in Construction, 93, 47- 62.

Shariatmadari, M., Nahavandi, N., Zegordi, S.H., \& Sobhiyah, M.H. (2017). Integrated resource management for simultaneous Project selection and scheduling. Computers and Industrial Engineering, 109, 3947.

Stanitsas, M., Kirytopoulos, K., \& Leoğoulos, V. (2021). Integrating sustainability indicators into project management: The case of construction industry. Journal of Cleaner Production, 279, 123774

Song, S., Yang, F., \& Xia, Q. (2019). Multi- criteria project portfolio selection and scheduling problem based on acceptability anaysis. Computers and Industrial Engineering, 135, 793- 799.

Tofighian, A.A., \& Naderi, B. (2015). Modeling and solving the project selection and scheduling. Computers and Industrial Engineering, 83, 30- 38.

Wu, Y., Xu, C., Ke, Y., Tao, Y., \& Li, X. (2019). Portfolio optimization of renewable energy projects under type2 fuzzy environment with sustainability perspective. Computers and Industrial Engineering, 133, 69- 82.

Zadeh, L. A. (1965). Fuzzy sets. Information and Control, 8, 338- 353.

Zarbakhshnia, N., Soleimani, H., \& Ghaderi, H. (2018). Sustainable third- part reverse logistics provider evaluation and selection using fuzzy SWARA and developed fuzzy COPRAS in the presence of risk criteria. Applied Soft Computing, 65, 307- 319

Zavadskas, E.K., Kaklauskas, A., \& Sarka, V. (1994). The new method of multiciriteria complex proportional assessment of projects. Technological and Economic Development of Economy, 1 (3),131- 139. 